UDC: $576.35+547.818+615.15$

\title{
Use of lectin as a vector molecule for delivery of medicinal products to cells and tissues
}

\author{
V. O. Antonyuk ${ }^{1}$, O. Yu. Klyuchivska ${ }^{1}$, R. V. Antonyuk ${ }^{2,3}$, A. V. Lozynskyi², \\ Kh. R. Pohranychna ${ }^{2}$, R. B. Lesyk ${ }^{2}$, R. S. Stoika ${ }^{1}$ \\ ${ }^{1}$ Institute of Cell Biology, NAS of Ukraine \\ 14/16, Drahomanov Str., Lviv, Ukraine, 79005 \\ 2 Danylo Halytsky Lviv National Medical University \\ 69, Pekarska Str., Lviv, Ukraine, 79010 \\ ${ }^{3}$ Dubno Central Regional Hospital \\ 73, Lvivska Str., Dubno, Rivne region, Ukraine \\ antonyukvo@gmail.com
}

\begin{abstract}
Aim. The conjugation of low-molecular compounds with antitumor activity to lectin and evaluation of the biological activity of the obtained conjugate. Methods. Organic synthesis; obtaining and analyzing Pisum sativum agglutinin with thiopyrano[2,3-d]thiazole derivative conjugate; its biological testing on cell cultures and histological samples. Results. A conjugate of the Pisum sativum lectin with the thiopyrano[2,3-d]thiazole derivative was obtained. Conjugation was carried out through the interaction of the aldehyde groups with the amino groups of lectin in the alkaline medium ( $\mathrm{pH} 9.0)$. The compound $(0.4 \mathrm{mg})$ was immobilized on lectin $(10 \mathrm{mg})$. Conjugation of pea lectin with the antineoplastic agent led to a $\sim 2.5$-fold increase in the inhibitory effect tested on a L1210 mouse leukemia cells line. The anti-neoplastic effect of the studied conjugate is fully manifested only on the third day after the beginning of experiment, possibly after penetration of the conjugate into cells and its desintegration. Conclusions. The results may be used for de-velopment of new drug delivery systems.
\end{abstract}

Ke y w o r d s: Pisum sativum agglutinin, thiopyrano[2,3- $d]$ thiazole, conjugate, delivery, antitumor activity.

\section{Introduction}

Lectins are proteins or glycoproteins of vegetable, microbial or animal origin that specifically bind the carbohydrate structure (simple carbohydrates or glycoconjugates) and cause no subsequent changes, unlike the glycosidases. Thus, lectins are a powerful tool for studying carbohydrates and their derivatives in solutions, as well as on the cell surface. They are widely used in the preparative and analytical methods in biochemistry, cell biology, immunology and related scientific branches, especially in the study of glycoconjugates. Therefore, an increasing number of investiga- tions on the application of lectins confirms their potentials in biology and medicine $[1,2]$. In addition, the promising direction of studies is the using of lectins for targeted delivery of drugs to specific cell types and tissues. Thus, the application of drug delivery system provides the advantages over the using of non-target drugs. This approach is important for preventing a local action of drugs on the healthy tissues and enhancing their action towards target cells. Various drug-delivery systems were proposed, for example, liposomes, lipoproteins, microspheres, nanoparticles, etc. [3].

The idea of using lectins for drug delivery was first suggested in 1988 by Woodley and Naisbett

(C) 2016 V. O. Antonyuk et al.; Published by the Institute of Molecular Biology and Genetics, NAS of Ukraine on behalf of Biopolymers and Cell. This is an Open Access article distributed under the terms of the Creative Commons Attribution License (http://creativecommons.org/licenses/by/4.0/), which permits unrestricted reuse, distribution, and reproduction in any medium, provided the original work is properly cited 
who proposed the applying of tomato lectin for drug delivery to luminal membrane of small intestine [4]. In 1976, the method was patented in the UK for treatment of dental caries based on using toothpaste that includes conjugates of Concanavalin A and dextrose [5]. The major disadvantage of lectins is their relatively high molecular mass. Thus, their administration can cause various side effects in blood stream (allergic reactions, antibodies formation). Therefore, the selective binding of the lectin can be used for the drug delivery to tissues of the intestinal tract, rectum, oral and nasal cavities, lung, eye, skin, but not for the direct administration into the bloodstream. The main advantage of lectins over the synthetic polymers is their biodegradability, as the proteins that are easily hydrolyzed by the lysosomal enzymes of the cells.

In order to use lectins as the transporting vector molecules, a biologically stable complex of lectin with the target drug should be created. The binding process can be accomplished through the specific interaction of the carbohydrate structure and the active group of drug or via covalent binding of the drug. In the first case the bonds between lectins and glycosides are weak, but the drug structure does not change. In the second case, chemical modification of the drug molecule and the lectin takes place, and this might affect the biological activity of the drug.

The purpose of our work was to perform the immobilization of low-molecular weight compound to the lectin molecule and evaluation of the biological activity of the created bio-conjugate.

\section{Materials and Methods}

We used synthesized thiopyrano[2,3- $d]$ thiazole derivative as a low-molecular weight ligand for the conjugation to the lectin (Figure 1). In previous studies, we reported thiopyrano[2,3- $d]$ thiazoles as potential antitripanosomal, antioxidant, anticancer and anti-inflammatory agents [6-8]. This target compound was covalently attached to the lectin of the pea seeds (PSA, Pisum sativum agglutinin). The lectin was isolated as described previously [9]. The conjugation was accomplished through the interac- tion between the aldehyde group of the target compound (Les-1351K) with the amino groups of the proteins in the alkaline medium ( $\mathrm{pH} 9.0)$.

\section{Conjugation}

The reaction of conjugation is based on the interaction of Les-1351K aldehyde groups with lectin's amino groups resulting in the formation of Shiff base and its subsequent reduction by sodium borohydride. $30 \mathrm{mg}$ of pea lectin were dissolved in $2.7 \mathrm{ml}$ of $0.15 \mathrm{M}$ carbonate buffer ( $\mathrm{pH} 9.0)$, split into three portions of $0.9 \mathrm{ml}$ and various amounts of a $10 \%$ solution of compound Les- $1351 \mathrm{~K}$, dissolved in $90^{\circ}$ ethanol $[0.05 \mathrm{ml}(0.5 \mathrm{mg}) ; 0.1 \mathrm{ml}(1 \mathrm{mg})$ and $0.2 \mathrm{ml}$ $(2 \mathrm{mg})]$ were added. The reaction mixture was left at room temperature for 48 hours, after that it was stopped by adding $0.1 \mathrm{ml}$ of ethylene glycol to each sample. Then after stirring for $10 \mathrm{~min} 5 \mathrm{mg}$ of sodium borohydride were added to each tube. The nonconjugated compound Les- $1351 \mathrm{~K}$ was withdrawn by the overnight dialysis against $50 \mathrm{ml}$ of $20^{\circ}$ ethanol, and then ethanol was removed by dialysis against $0.05 \mathrm{M}$ carbonate buffer ( $\mathrm{pH}$ 8.0). The dialysis against slightly alkaline buffer solution is necessary because of a better solubility of pea lectins in the alkaline medium.

\section{Investigation of the obtained conjugate}

The lectin activity (an ability to bind the specific carbohydrates and glycoproteins of the cell membrane), and the total protein and Les- $1351 \mathrm{~K}$ compound content are the important characteristics of the obtained conjugate. The lectin activity before and after conjugation was measured by determining the agglutination titer of $2 \%$ suspension of the group A human erythrocytes in the buffered saline, as described previously [1]. The content of the target Les$1351 \mathrm{~K}$ compound in $1 \mathrm{mg}$ of conjugate was measured by absorbance assay at $310 \mathrm{~nm}$ with formulae: $\mathrm{C}_{\%}=\left(\mathrm{A}_{310} \times \mathrm{K}-\mathrm{A}_{310 \mathrm{~L}} \times \mathrm{C}_{\mathrm{PSA}}\right) \times 100 \%$, where $\mathrm{A}_{310}$ is the absorbance of conjugate, $\mathrm{A}_{310 \mathrm{~L}}$ is the absorbance of lectin, $K=0,094$ as coefficient of increasing of extinction per unit concentration, $\mathrm{C}_{\mathrm{PSA}}=$ content of lectin. The protein concentration in the pea lectin so- 
lution was also measured spectrophotometrically at $740 \mathrm{~nm}$ by Lowri method. In parallel we determined hemagglutination titer by rabbit erythrocytes for the measurement concentration of lectin (1\% PSA has titer rabbit agglutination in $1: 2048)$.

Synthesis of 7-\{2-[(2-chlorobenzyl)oxy]-5-nitrophenyl\}-2-oxo-3,5, 6,7-tetrahydro-2H-thiopyrano[2,3- $d][1,3]$ thiazole-6-carbaldehyde (Les-1351) was performed as described previously [10]. Target derivative Les-1351K was obtained via reaction of Les-1351 and potassium hydroxide in ethanol medium.

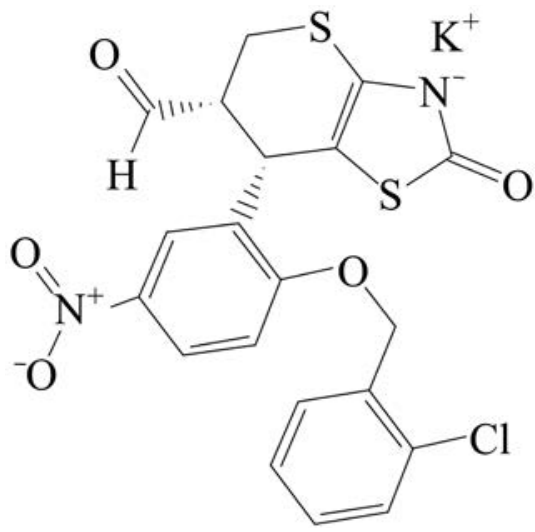

Fig.1. Structure of the investigated thiopyrano[2,3- $d]$ thiazole - compound Les-1351K

\section{Cell culture}

The murine leukemia cells of L 1210 line were obtained from Cell culture collection of R. E. Kavetsky Institute of Experimental Pathology, Oncology and Radiobiology, National Academy of Sciences of Ukraine. Cells were cultured in the Dulbecco's modified Eagle's medium (DMEM, Sigma Chem. Co, St. Louis, USA) supplemented with $10 \%$ fetal bovine serum (Sigma), $50 \mu \mathrm{g} / \mathrm{ml}$ streptomycin ("Sigma") and phenol red used as $\mathrm{pH}$ indicator. The color change from yellow to red can indicate the cell viability. To determine the cytotoxic action of the Pisum sativum lectin, Les- $1351 \mathrm{~K}$ compound and their conjugate on the cells cultured were sown in 96-well plastic plates in DMEM medium supplemented with $10 \%$ fetal bovine serum, and the tested substances in different concentrations were added. Doxorubicin (Ukraine) was used as a positive control. The counting of cell number was carried out using Phenol Red dye (DV-T10282, Invitrogen, USA) at different intervals in the hemocytometric chamber. The dead cells uptake this dye to the damage of their plasma membrane. Thus, the cells colored in blue are pronecrotic ones. Cell density in suspension was counted using the following formula: $\mathrm{c}=12500 \mathrm{n}$, where: $\mathrm{c}-$ number of cells in $1 \mathrm{ml}$ of suspension, $\mathrm{n}-$ average number of cells in 5 large squares of the hemocytometer.

\section{Histological study}

For histological study, the autopsy material of human colon was used. The histological specimens were fixed in formalin, then washed, and dehydrated in the ascending alcohols, lighted in xylene and embedded in the paraffin wax. For tissue morphology study, 5- to 7- $\mu \mathrm{m}$-thick sections were stained with Hematoxylin and Eosin using known procedure.

\section{The preparation of the Pisum sativum lectin labelled with colloidal gold}

To detect carbohydrate determinants of the pea lectin conjugate, the labelling with colloidal gold was used. The $15 \mathrm{~nm}$ colloidal gold particles were prepared as described previously [11]. Synthesis of colloidal gold particles was performed by reducing $0.01 \% \mathrm{HAuCl}_{4}$ with potassium citrate dihydrate. Concentration of the particles was determined by measuring the extinction of colloid solution at $\mathrm{A}_{520} \mathrm{~nm} .0 .25 \mathrm{ml}$ of $10 \%$ solution polyvinylpyrrolidone $(\mathrm{Mw}=24 \mathrm{kDa})$ and $5.0 \mathrm{ml}$ of $0.1 \mathrm{M}$ acetate buffer ( $\mathrm{pH}$ 6.0) were added to $50 \mathrm{ml}$ of colloidal gold $\left(\mathrm{A}_{520}=5.0\right)$ for stabilization. To resulting colloid, the pea lectin in the same acetate buffer was added. The amount of introduced lectin was determined experimentally by using non-stabilized (without polyvinylpyrrolidone) gold particles.

\section{Detection of lectin binding in cells}

The histological sections were prepared according to the standard protocol and proved after dewaxing with water, then incubated for $60 \mathrm{~min}$ in a solution of gold-labeled Pisum sativum lectin at room temperature. After washing the non-conjugated lectins a so- 


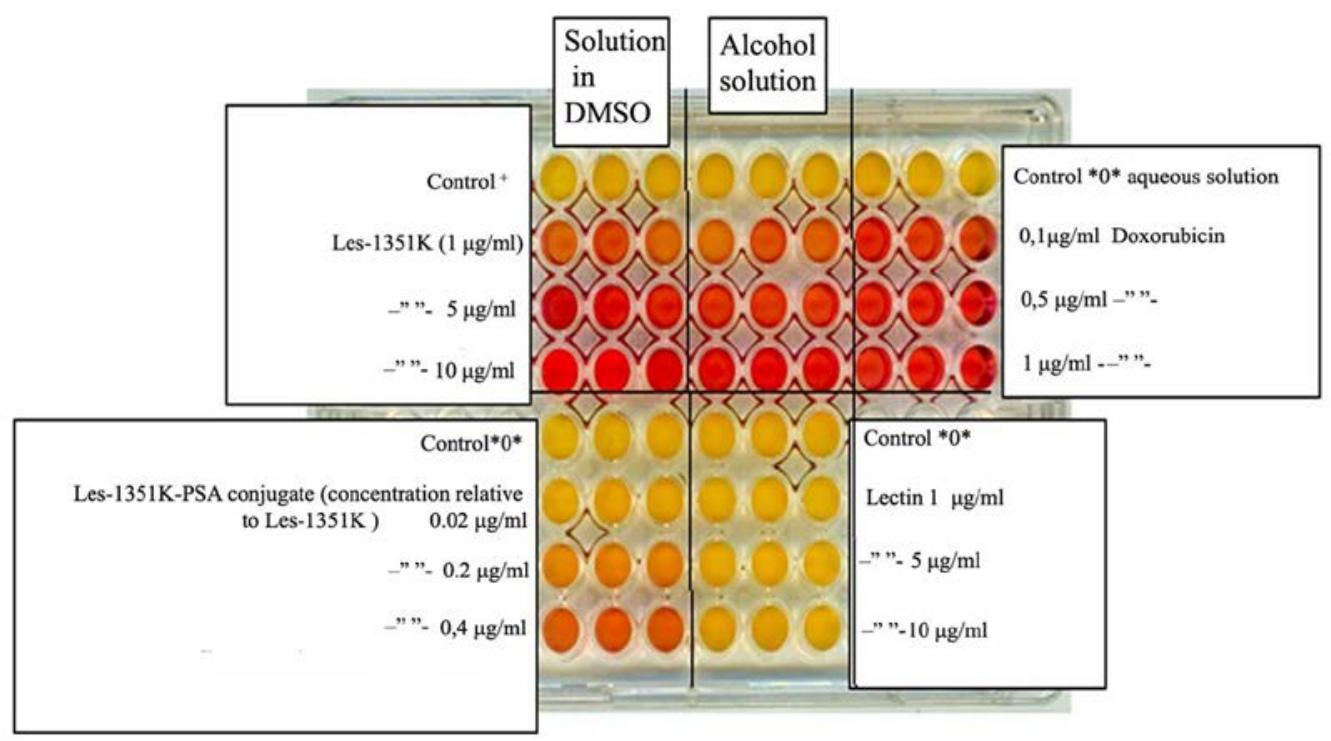

Fig. 2. The effect of pea lectin, doxorubicin, Les-1351K, and Les-1351K conjugate with pea lectin towards murine leukemia L1210 cells after 72-h treatment (According to the Phenol Red test) lution of silver acetate in the hydroquinone developer prepared in $0.1 \mathrm{M}$ citrate buffer $(\mathrm{pH} 3.5)$ was added. Such treatment is needed in order to make the gold particles invisible under the light microscope when imaging is amplified by the silver salts [12]. Accumulation of the metallic silver occurs in the sites of localisation of colloidal gold particles that are clearly visible under the light microscope (similar to silver impregnation). The process was controlled under the microscope in order to avoid an excessive accumulation of silver. The displaying process with silver acetate was performed for 10 $15 \mathrm{~min}$.

\section{Results and Discussion}

Solubility of lectins in water or in the medium where denaturation of proteins does not proceed is an important condition for effective ligand binding. These media include water-saline solutions with alcohol of different concentration (20-30\%) or other organic solvents (such 20-30 \% DMSO solution). The Les$1351 \mathrm{~K}$ is soluble in DMSO, ethanol and water-ethanol mixtures that facilitates obtaining of conjugates. Besides, the presence of the aldehyde group in structure of the target compound makes possible the attachment of the proteins under soft conditions without their denaturation. According to the calculations,
$10 \mathrm{mg}$ of lectin conjugate contain approximately $0.4 \mathrm{mg}$ of the studied compound ( $4 \%$ of the total conjugate weight). The obtained conjugate was soluble in water, $30 \%$ DMSO, but insoluble in the organic solvents. A high level of the compound Les$1351 \mathrm{~K}$ in the conjugate can cause a loss of its solubility and formation of the precipitate.

The results of cytotoxicity measuring of the obtained conjugate towards the murine leukemia L1210 cell line are depicted in Fig. 2. The color changing of phenol red in well plates from yellow to

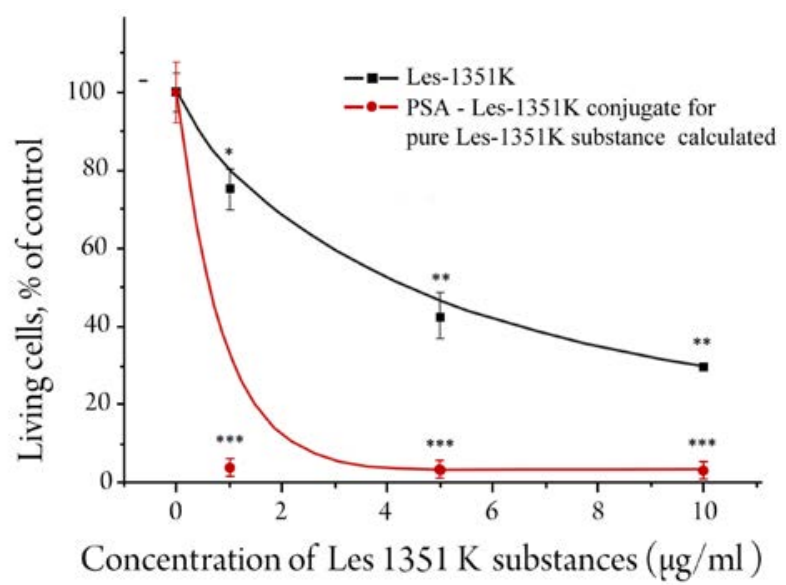

Fig. 3. The effect of Les-1351K and Les-1351K conjugate with the pea lectin towards the murine leukemia L1210 cell line (calculated for pure Les-1351K, according to the Phenol Red test). 
red indicates the appearance of dead cells. As a result, Les-1351K displays high level of the antineoplastic activity, although it was 10 times less than that of the doxorubicin. The pea lectin $(10 \mathrm{mg} / \mathrm{ml})$ was completely non-toxic for the murine leukemia L1210 cells. The conjugate of pea lectin with Les$1351 \mathrm{~K}$ in $10 \mathrm{mg} / \mathrm{ml}$ concentration displays the same action as Les- $1351 \mathrm{~K}$ in $1 \mathrm{mg} / \mathrm{ml}$ dose. As a result, the activity of studied compound increased more than 2.5 fold after its conjugation with the pea lectin.

While the murine leukemia L1210 cells growing in suspension culture were dying under the action of both Doxorubicin and Les-1351K, the cytotoxic effect of these agents towards the human embryonic kidney HEK-293 cells growing in a monolayer culture (attached) was less expressed, especially in the case of cell treatment with Les-1351K (Fig.4). This compound did not affect the human breast carcinoma MCF-7 cells (epithelial origin) also growing in the monolayer culture. Doxorubicin was cytotoxic for the MCF-7 cells, although to much lower extent than for the leukemia L1210 cells and the pseudonormal HEK-293 cells.

An important factor for increasing the toxicity towards the murine leukemia L1210 cells is a selective binding of the cytotoxic agent with the carbohydratecontaining receptors on a cell surface, including tissues containing the cells of different types. Notably, the action of Les-1351K-lectin conjugate was well manifested only on the third day after the start of the experiment. Thus, Les- $1351 \mathrm{~K}$ initially penetrated into the cell, disconnected from the conjugate, and then expressed their activity. Penetration of the lectin conjugate into the cells might occur by the pinocytosis, as it happens with free lectins. Ligand's release in the cells could be carried out by the lysosomal enzymes, as it occurs at the release of other proteins.

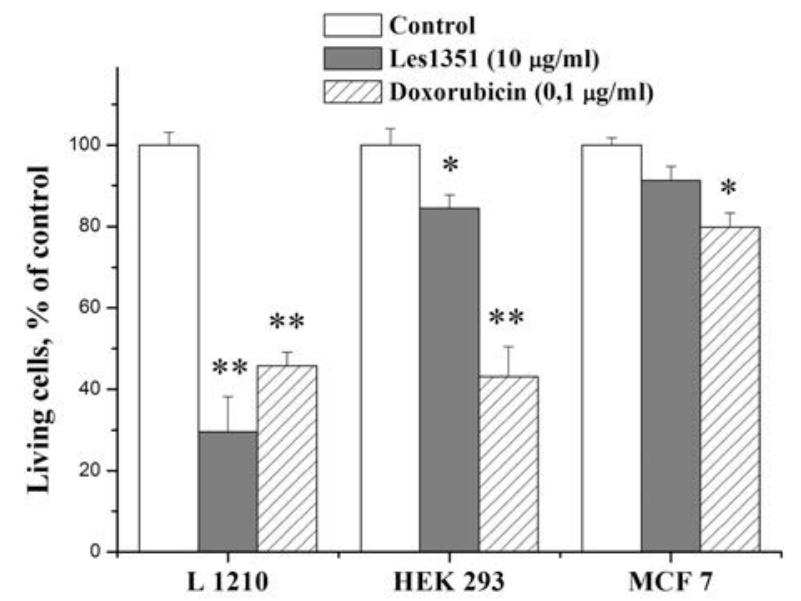

Fig. 4. The effect of Les-1351K and doxorubicin on the murine leukemia L1210, human embryonic kidney HEK-293 and human breast carcinoma MCF-7 cells.

$* \mathrm{P}<0.05, * * \mathrm{P}<0.01$

It should be noted that $\mathrm{EC}_{50}$ for Les $1351 \mathrm{~K}$ and Les- $1351 \mathrm{~K}$ conjugate are integral index that depended on the duration of the experiment. The data of these experiments is presented in table 1

The staining of the colon with the pea lectin labeled with colloidal gold was performed. A selectivity of binding this substance with several histological structures was found, especially with the mucin of the goblet cells (including the membrane vesicles) (Figure 5).

The use of colon as tissue for the interaction of its cells with the pea lectin demonstrated that the inner surface of the intestinal tract possesses the binding sites for the conjugate. In particular, administration of such conjugate to the ointment or suppository basis could be promising for the treatment of rectal cancer. For example, in our previous investigation it was found that the lectin from carp roe and Phaseolus vulgaris erythroagglutinin were not bound by normal colon tissue, however, higher affinity of these

Table 1. Value of $\mathbf{E C}_{\mathbf{5 0}}$ for Les-1351K-conjugate in dependent on the duration of the experiment

\begin{tabular}{|l|c|c|}
\hline \multicolumn{1}{|c|}{$\mathrm{EC}_{50}, \mu \mathrm{g} / \mathrm{ml}$} & $24 \mathrm{~h}$ & $48 \mathrm{~h}$ \\
\hline Phenol red (cytotoxicity testing) & $\sim 10$ & $\sim 8,3$ \\
MTT (metabolic testing) & $\geq 10$ & $72 \mathrm{~h}$ \\
\hline
\end{tabular}




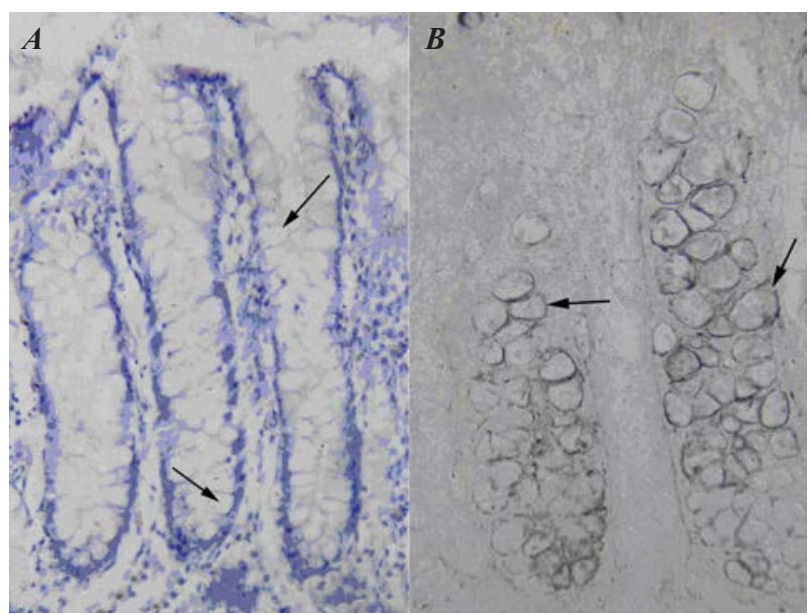

Fig. 5. The human colon mucose histological preparation. $A-$ Hematoxylin \& eosin staining; $B$ - PSA-colloidal gold staining. The secretory granules of the goblet cells (noted by arrows).

lectins to well differentiated colon adenocarcinomas was demonstrated [13]. The conjugation of these lectins with Les-1351K can be performed by using the described method.

Lectins possess certain limitations of their using as drugs (see "Introduction"). Thus, they should be used only for external application, in particular, at the treatment of the diseases of skin, intestinal tract, nasal cavity, lung or as a basis of various rinses and sprays, suppositories and ointment bases, but not for administration through the bloodstream. The obtained results revealed that the lectins application could be a perspective model for developing ligandtargeted drugs. Thus, the creation of more effective drugs with a higher concentration of active ingredients in some histological structures is an important approach in medicinal chemistry.

\section{Conclusions}

1. The investigation of the interaction of the pea lectin conjugate with the anticancer agent Les-1351K revealed a 2.5 fold increasing of the antineoplastic activity of this compound towards the murine leukemia L1210 cell line.

2 . The enhancement of action of the conjugate towards the target cells could be explained by selective binding of the glycoconjugate with the cell surface which is provided by lectin's component in the conjugate. The antineoplastic activity of the tested conjugate is observed on the third day, probably after the accomplishment of the conjugate into the target cells and the decomposition of the conjugate with a release of the anticancer agent.

3. The obtained results are of interest for elaboration of novel drug delivery systems.

\section{REFERENCES}

1. Antonyuk VO. The lectins and their resources. Lviv: Quart, 2005; $554 \mathrm{p}$.

2. Sybirna NO, Schewtsova AI, Ushakova GO. The Fundamentals of glycobiology. Lviv: LNU, 2015; 492 p.

3. Molema G. Drug targeting: basic concepts and novel advances. In: Drug targeting organ-specific strategies, Eds Molena G, Meijer DKF. Wiley-VCH Verlag GmbH, Weinheim. 2001. $406 \mathrm{p}$.

4. Woodley JF, Naisbett B. The potential of lectins for delaying the intestinal transit of drugs. Proc Int Symp Control Rel Bioact. Mater. 1988; 15: 125-6.

5. Pat. 143359 English, $1 C 2$ A $61 \mathrm{~K} 37 / 00$ C 07G 7/0-2. Conjugates. William H. Bowen, Sidney A. Barker. Publ. 28.04.76.

6. Lesyk RB, Zimenkovsky BS. 4-Thiazolidones: centenarian history, current status and perspectives for modern organic and medicinal chemistry. Curr Org Chem. 2004; 8(16):1547-77.

7. Lozynskyi AV, Kaminskyy DV, Romanchyshyn KhB, Semenciv $N G$, Ogurtsov VV, Nektegayev IO, Lesyk RB. Screening of antioxidant and anti-inflammatory activity among thiopyrano[2,3-d]thiazoles. Biopolym Cell. 2015; 31(2):131-7.

8. Zelisko N, Atamanyuk D, Vasylenko O, Grellier P, Lesyk R. Synthesis and antitrypanosomal activity of new 6,6,7-trisubstituted thiopyrano[2,3-d][1,3]thiazoles. Bioorg Med Chem Lett. 2012;22(23):7071-4.

9. Antonyuk VO. The method of purification of mannose-specific lectins. Declarative patent of Ukraine No 13770, published 17.04.2006, claim for u200510008.

10. Lozynskyi A, Golota S, Zimenkovsky B, Atamanyuk D, Gzella A, Lesyk R. Synthesis, anticancer and antiviral activities of novel thiopyrano[2,3-d]thiazole-6-carbaldehydes. Phosphorus Sulfur Silicon Relat Elem. 2016; 191:1245-9.

11. Chomutovskyj OA, Lutsyk MD, Perederej OF. Electronichistochemistry of cell membrane receptors. Kyiv: Naukova dumka, 1986; $168 \mathrm{p}$.

12. Hayat MA. Colloidal Gold: principles, methods, and applications. New York: Academic Press, 2012. 536 p.

13. Antonyuk RV, Lutsyk AD, Antonyuk VO. Research of carbohydrate specificity and application in histoshemistry lectin from carp roe (Cyprinus carpio L.). International Sympo- 
sium on Cell Biology jointly with 5th Ukrainian Congress for Cell Biology. Odesa. Abstracts book. 2016:64

\section{Використання лектину як векторної молекули для доставки лікарських засобів до клітин і тканин}

В. О. Антонюк, О. Ю. Ключівська, Р. В. Антонюк, А. В. Лозинський, Х. Р. Погранична, Р. Б. Лесик, P. С. Стойка

Мета. Приєднання низькомолекулярної сполуки 3 протипухлинною активністю до лектину та визначення біологічної активності одержаного кон'югату. Методи. Органічний синтез; одержання та аналіз кон'югату лектину гороху 3 похідним тіопірано[2,3-d]тіазолу, біотестування кон'югату на культурі клітин та гістологічних препаратах. Результати. Одержано кон'югат лектину гороху (Pisum sativum) приєднаним похідним тіопірано[2,3-d]тіазолу. Кон'югацію здійснювали через взаємодію альдегідної групи сполуки похідного з аміногрупами білка лектину в лужному середовищі (pH 9,0). До 10 мг лектину було приєднано $\approx 0,4$ мг досліджуваної сполуки. Кон'югація лектину гороху 3 протипухлинною речовиною спричинила підсилення інгібувальної дії останньої на клітини лінії L1210 лейкозу миші приблизно у 2,5 рази (у перерахунку на речовину). Антинеопластична дія кон'югату в повній мірі проявляється лише на третю добу від початку досліду, й імовірно після проникнення кон'югату у клітину і розпаду молекули. На гістологічному препараті визначено особливості зв'язування досліджуваного кон'югату з мукозними клітинами прямої кишки людини. Висновки. Одержані результати можуть бути цікавими для моделювання адресної доставки біологічно активних речовин в клітини тканин організму.

Кл юч о в і с л о в а: Pisum sativum agglutinin, тіопірано[2,3-d] тіазоли, кон'югат, доставка, протипухлинна активність.
Использование лектина как векторной молекулы для доставки лекарственных средств в клетки и ткани.

В. О. Антонюк, О. Ю. Ключивская, Р. В. Антонюк, А. В. Лозинский, Х. Р. Погранычна, Р. Б. Лесык, Р. С. Стойка

Цель. присоединение низкомолекулярного соединения с противоопухолевой активностью к лектину и проверка биологической активности полученного конъюгата. Методы. Органический синтез; получение и анализ конъюгата лектина гороха с производным тиопирано[2,3- $d$ ]тиазола, биотестирование конъюгата на культуре клеток и гистологических препаратах. Результаты. Получен конъюгат лектина гороха (Pisum sativum) с присоединенным производным тиопирано[2,3-d]тиазола. Конъюгацию осуществляли через взаимодействие альдегидной группы соединения производного с аминогруппами белка лектина в щелочной среде $(\mathrm{pH} 9,0)$. К 10 мг лектина было присоединено $\approx 0,4$ мг исследуемого соединения. Конъюгация лектина гороха с противоопухолевым веществом вызвала усиление ингибирующего действия вещества на клетки линии L1210 лейкоза мыши примерно в 2,5 раза (в пересчете на вещество). Антинеопластическое действие конъюгата в полной мере проявляется лишь на третьи сутки от начала опыта, и вероятно после проникновения конъюгата в клетку и распада молекулы. На гистологическом препарате определены особенности связывания исследуемого конъюгата с мукозными клетками прямой кишки человека Выводы. Полученные результаты представляют интерес для моделирования адресной доставки биологически активных веществ в клетки тканей организма.

Ключевые слова: Pisum sativum agglutinin, тиопирано[2,3-d]тиазолы, конъюгаты, доставка, противоопухолевая активность. 